\title{
Paleomagnetism of the latest Precambrian/Cambrian Unicoi basalts from the Blue Ridge, northeast Tennessee and southwest Virginia: evidence for Taconic deformation
}

\author{
Peter M. Brown and Rob Van der Voo \\ Deparıment of Geological Sciences, University of Michigan, Ann Arbor, MI 48109 (U.S.A.)
}

Received July 7, 1981

Revised version received July 5, 1982

\begin{abstract}
Three components of magnetization have been observed in ninety-six samples (twelve sites) of amygdaloidal basalts and "sedimentary greenstones" of the Unicoi Formation in the Blue Ridge Province of northeast Tennessee and southwest Virginia. These components could be isolated by alternating field as well as thermal demagnetization. One component, with a direction close to that of the present-day geomagnetic field is ascribed to recent viscous remanent magnetizations; another component, with intermediate blocking temperatures and coercivities, gives a mean direction of $D=132^{\circ}, I=+43^{\circ}, \alpha_{95}=9^{\circ}$ for $N=10$ sites before correction for tilt of the strata. This direction and the corresponding pole position are close to Ordovician/Silurian data from the North American craton and we infer this magnetization to be due to a thermal(?) remagnetization during or after the Taconic orogeny. This magnetization is of post-folding origin, which indicates that the Blue Ridge in our area was structurally affected by the Taconic deformation. The third component, with the highest blocking temperatures and coercivities, appears to reside in hematite. Its mean direction, $D=276^{\circ}, I=-17^{\circ}, \alpha_{95}=13.8^{\circ}$ for $N=6$ sites (after tilt correction) corresponds 10 a pole close 10 Latest Precambrian and Cambrian poles for North America. The fold test is inconclusive for this magnetization at the $95 \%$ confidence level because of the near-coincidence of the strike and the declinations. We infer this direction to be due to early high-temperature oxidation of the basalts, and argue that its magnetization may have survived the later thermal events because of its intrinsic high blocking temperatures. A detailed examination of the paleomagnetic directions from this study reveals that the Blue Ridge in this area may have undergone a small counterclockwise rotation of about $15^{\circ}$.
\end{abstract}

\section{Introduction}

Paleomagnetism is a very powerful tool for unravelling the tectonic history of allochthonous and/or peri-cratonic terranes. If an apparent polar wander path has been reasonably well established for the craton, a comparison of poles obtained from peri-cratonic terranes can reveal rotations or large-scale displacements. In addition, poles obtained from rocks that have been metamorphosed, or directions from stratified rocks in combination with a fold test [1], can sometimes be used to determine or constrain the age of tectonic activity in the area.
The allochthonous nature of the Blue Ridge Province in the southern Appalachians has been well established by the COCORP seismological data [2], but these data can give no information about the nature or magnitude of the displacement. The area has undergone several orogenic phases such as the Taconic, Alleghenian and possibly the Acadian. Thus paleomagnetic data from the Blue Ridge could yield much information about the tectonic history of the province. With this in mind the present study of the latest Precambrian/Early Cambrian Unicoi basalts of the Blue Ridge Province was undertaken.

Several features of the Unicoi basalt flows make 
it likely that a paleopole (or paleopoles) obtained from them will yield useful information about the tectonic history of the Blue Ridge when compared to other poles from the North American craton $[3,4]$. As basalt flows, they are stratified rocks, and can thus be restored to the paleohorizontal. Moreover, basalts in general are likely to have recorded the magnetic field present when they were extruded, in this case at about the beginning of the Paleozoic. So even if rotation or displacement took place later in the Paleozoic, it would still be detectable. The basalts have been only mildly metamorphosed and folded, so depending on the sequence of these events, and with a fold test, it might be possible to assign an age to the tectonic activity.

\section{Geologic setting}

The Latest Precambrian to Earliest Cambrian Unicoi Formation is the lowest formation of the Chilhowie Group within the Blue Ridge tectonic province of the Appalachians in northeast Tennessee and southwest Virginia (Fig. 1). The geology of this area has been described by King and Ferguson [5] and Rankin [6]. In northeast Tennessee and southwest Virginia, the Unicoi occurs in the Shady Valley Thrust sheet between the Holston Mountain Fault and the Iron Mountain Fault, and in the Mountain City Window near the Stone Mountain Fault (adjacent to the North Carolina border). The Chilhowie Group lies unconformably on the Late Precambrian Mount Rodgers volcanic group. It has a maximum thickness of $2300 \mathrm{~m}$ and an average thickness of about $1200 \mathrm{~m}$. The Unicoi Formation is even more variable in thickness: in most sections it is $600 \mathrm{~m}$ thick, but the total thickness sometimes reaches $1500 \mathrm{~m}$. It can be separated into upper and lower divisions. The upper division consists of thick-bedded quartzite, in part arkosic and conglomeratic, and intercalated thin-bedded, sometimes shaly, arkose. The lower division consists of arkose, shale and conglomerate.

The amygdaloidal basalt flows of the Unicoi Formation occur among conglomerate and arkose in the lower division and in the lowest part of the

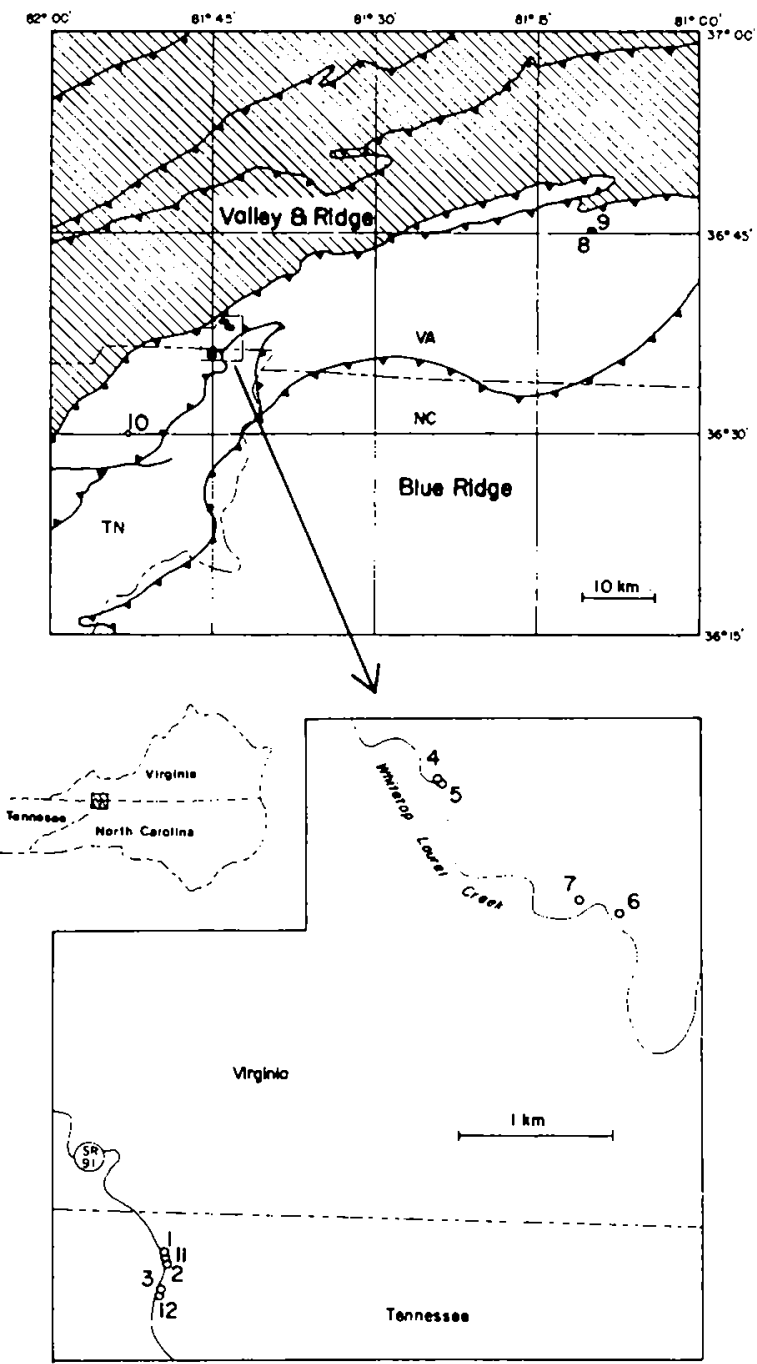

Fig. 1. Map of the northeastern Tennessee and southwest Virginia area of the sampling sites of the Unicoi basalts in the Blue Ridge Province.

upper division. The flows are localized and discontinuous [5], although the uppermost basalt flow may be more widespread [6]. The discontinuous flows are found at different stratigraphic levels from section to section. Within a given section there may be no basalt flow present or there may be as many as three separate flows with up to $250 \mathrm{~m}$ of sediments in between. Most commonly two flows are found. Associated with the basalt, in places apparently occupying the same stratigraphic 
position as nearby basalt flows, are green, indurated sedimentary rocks termed "sedimentary greenstones" by King and Ferguson [5]. This lithology was sampled at sites 8 and 9 .

Regional metamorphism of the Blue Ridge rocks in this area is low-grade; the highest-grade metamorphism seen is greenschist facies. Reflected-light microscopy studies supplemented in some cases by electron microprobe analysis revealed that the magnetic minerals present vary from site to site. Samples from sites 3 and 6 contain lathes of ilmenite which are partially altered to hematite. Samples from sites 1 and 5 have large, skeletal grains of magnetite which are partially altered to hematite, and also some chalcopyrite. Site 2 and 7 have the ilmenite lathes as well as the skeletal magnetite grains, both partially altered to hematite. Site 4 has small, angular grains of magnetite, partially altered to hematite, and a small amount of ilmenite lathes. At sites 8 and 9, the "sedimentary greenstone" is sampled. Site 8 has large, rounded magnetite grains, some partially altered to hematite. Site 9 has only a small amount of magnetite which has precipitated between grains.

\section{Methods and results}

Samples were collected at twelve sites (Fig. 1). Because of the discontinuous nature of the flows, it is unlikely that any of the widely separated sites are from the same flow. Of the sites that are close together, sites 1 and 11 are from the same flow but site 2 is from a different flow, sites 3 and 12 are from the same flow and sites 4 and 5 are from different flows.

Oriented core samples were drilled in the field. These samples were cut into specimens, generally two per sample. To analyze the natural remanent magnetizations (NRM's), the specimens were treated with progressive alternating field and thermal demagnetization. Usually about ten demagnetization steps were carried out for each specimen, with at least six steps in all cases. A demagnetization diagram [7] was made for each specimen. Three characteristic directions of magnetization were found, with usually two but in some cases all three occurring in an individual sample. All three components of magnetization were resolved by both thermal and alternating field treatment, although in some cases the hardest component could not be removed using alternating field demagnetization up to $100 \mathrm{mT}$.

The three characteristic directions in the samples are as follows: a direction with northerly declination and moderately downward inclination which corresponds to the present-day magnetic field (PDF) in the study area; a direction with southeasterly declination and intermediate downward inclination which could correspond to an Ordovician direction for cratonic North America; and a direction with easterly or westerly declinations and shallow inclinations we interpret as corresponding to a Latest Precambrian/Cambrian direction for cratonic North America. Site means for the latter two directions are given in Table 1. Two sites (9 and 10) did not yield stable or consistent results, and several samples contained only PDF directions.

Fig. 2 is a $\mathrm{Zijderveld} \mathrm{plot} \mathrm{(in-situ} \mathrm{coordinates)}$ of the results of a thermal demagnetization. Two of the three characteristic directions of magnetization are found in this sample. The direction corresponding to PDF is removed below $520^{\circ} \mathrm{C}$. Above $520^{\circ} \mathrm{C}$ the intermediate direction is being removed. The magnetization is completely eliminated at temperatures between 580 and $600^{\circ} \mathrm{C}$. Fig. 3 shows Zijderveld plots of two specimens of another sample, plotted in-situ. Specimen RAU 20A is treated with progressive alternating field demagnetization up to $90 \mathrm{mT}$, and then with progressive thermal demagnetization from 540 to $700^{\circ} \mathrm{C}$. Specimen RAU 20B is treated just thermally. All three components of magnetization are found in this sample, as is best seen in the horizontal parts of the plots. First the direction corresponding to PDF is removed up to $80 \mathrm{mT}$ or $250^{\circ} \mathrm{C}$. Then between $80 \mathrm{mT}$ and $540^{\circ} \mathrm{C}$, or between 250 and $540^{\circ} \mathrm{C}$, the intermediate direction is being removed. Above $540^{\circ} \mathrm{C}$, the Latest Precambrian/ Cambrian direction is removed. The latter magnetization persists up to $685^{\circ} \mathrm{C}$.

Isothermal remanent magnetization (IRM) acquisition experiments were carried out on samples from each of the sites. The samples were treated with progressively higher fields up to $2.0 \mathrm{~T}$, 
TABLE 1

Summary of site-mean paleomagnetic directions

\begin{tabular}{|c|c|c|c|c|c|c|c|c|c|c|}
\hline \multirow[t]{2}{*}{ Site } & \multicolumn{5}{|c|}{ Intermediate (Taconic?) directions } & \multicolumn{5}{|c|}{ High-coercivity, high-blocking $T$ directions } \\
\hline & $\begin{array}{l}D / I \\
\text { before TC }\end{array}$ & $\begin{array}{l}D / I \\
\text { after TC }\end{array}$ & $k$ & $\alpha_{95}$ & $N_{\mathrm{s}}$ & $\begin{array}{l}D / I \\
\text { before TC }\end{array}$ & $\begin{array}{l}D / I \\
\text { after TC }\end{array}$ & $k$ & $\alpha_{9 s}$ & $N_{s}$ \\
\hline 1 & $131.8 /+30.8$ & $124.3 /+58.9$ & 25.9 & 9.7 & $10 / 10$ & - & - & - & - & $0 / 10$ \\
\hline 2 & $129.6 /+33.9$ & $119.1 /+61.5$ & 50.4 & 9.5 & $6 / 6$ & $90.0 /-2.0$ & $88.0 /+15.0$ & - & - & $1 / 6$ \\
\hline 3 & $144.9 /+42.2$ & $146.9 /+71.2$ & 7.8 & 47.6 & $3 / 7$ & $291.0 /-18.4$ & $292.7 /-6.7$ & 59.2 & 8.8 & $6 / 7$ \\
\hline 4 & $129.5 /+50.6$ & $130.2 /+27.2$ & 88.0 & 8.2 & $5 / 7$ & - & - & - & - & $0 / 7$ \\
\hline 5 & $126.7 /+56.3$ & $128.5 /+32.9$ & 98.5 & 9.3 & $4 / 5$ & - & - & - & - & $0 / 5$ \\
\hline 6 & $152.0 /+67.0$ & $61.0 /+82.0$ & - & - & $1 / 6$ & $263.5 /-2.0$ & $262.5 /-2.5$ & 139.1 & 7.8 & $4 / 6$ \\
\hline 7 & $113.8 /+50.1$ & $84.6 /+69.9$ & - & - & $2 / 5$ & - & - & - & - & $0 / 5$ \\
\hline 8 & $133.0 /+23.0$ & $119.0 /-44.0$ & - & - & $1 / 9$ & $296.0 /+14.0$ & $282.0 /-38.0$ & - & - & $1 / 9$ \\
\hline 9 & - & - & - & - & $0 / 9$ & - & - & - & - & $0 / 9$ \\
\hline 10 & - & - & - & - & $0 / 11$ & - & - & - & - & $0 / 11$ \\
\hline 11 & $133.3 /+31.4$ & $126.7 /+59.7$ & 19.2 & 15.7 & $6 / 11$ & $97.6 /+3.4$ & $92.2 /+23.1$ & 49.9 & 10.9 & $5 / 11$ \\
\hline 12 & $128.7 /+39.0$ & $114.4 /+65.9$ & 12.1 & 27.5 & $4 / 10$ & $279.0 /+7.8$ & $278.3 /-13.2$ & 12.1 & 20.1 & $6 / 10$ \\
\hline
\end{tabular}

$D / /$ are the declination and inclination in degrees; $k$ and $\alpha_{95}$ are the statistical parameters associated with the mean directions. giving unit weight to samples; $N_{s}$ is the ratio of samples used for the computation of the mean to the number of samples analyzed.

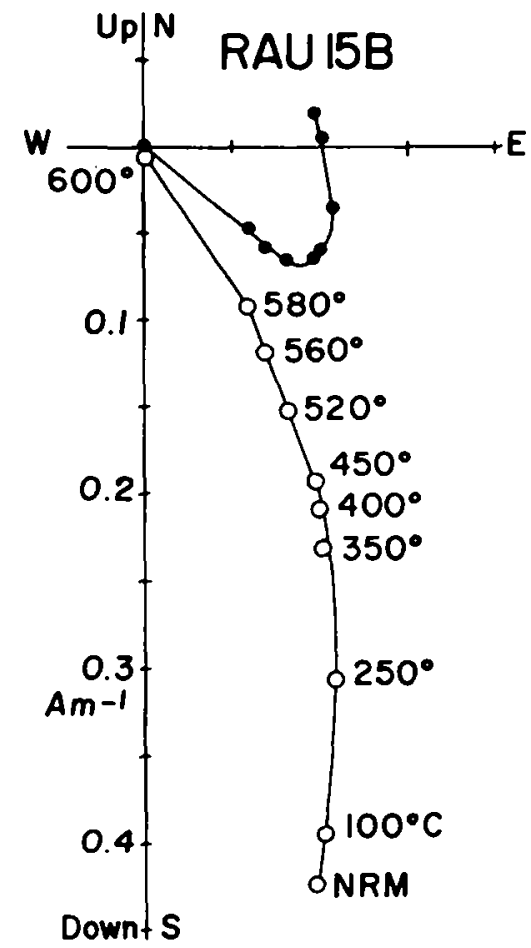

Fig. 2. Orthogonal demagnetization diagram [7] of the successive end points of the magnetization vector during progressive thermal demagnetization of a sample from site 4 . Solid circles represent projections on the horizontal plane, open circles those on the east-west vertical plane.

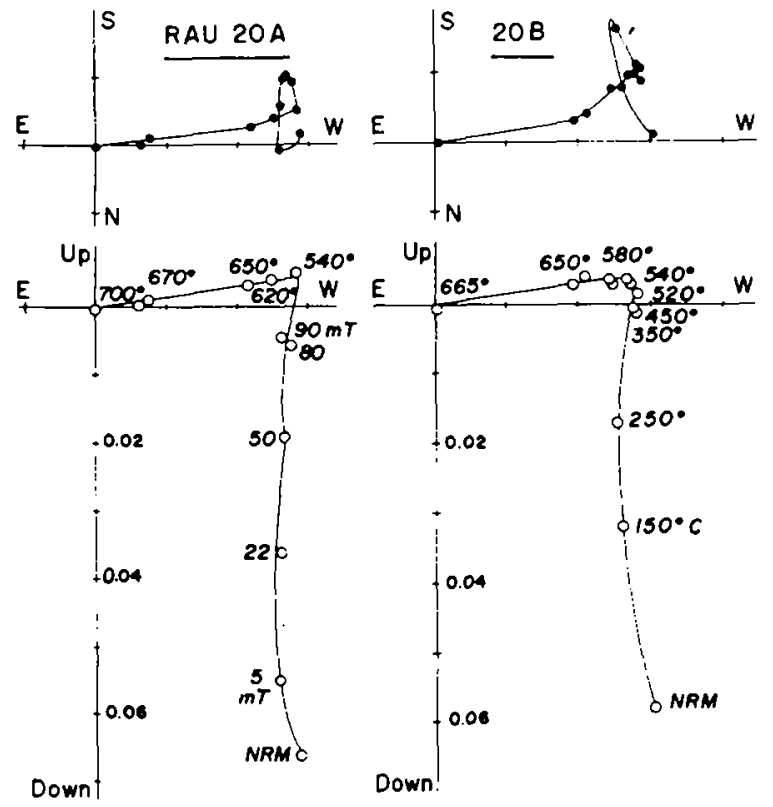

Fig. 3. Orthogonal demagnetization diagrams, as in Fig. 2, of two specimens from the same sample of site 6 . The horizontal plots (top) have been separated from the east-west vertical plots (bottom) for clarity. 
removed from the field after each treatment, and the intensity of the resulting remanence measured. Two types of behavior were observed in the IRM acquisition. The results of the experiment for samples representing each type are shown in Fig. 4, along with plots of the change of NRM intensity during thermal demagnetization for different specimens of the same samples for which the IRM acquisition results are shown.

The magnetization of sample RAU 15 included the intermediate direction, but not the high coercivity/high blocking temperature direction (Fig. 2). RAU 15 acquires IRM very rapidly with increas-
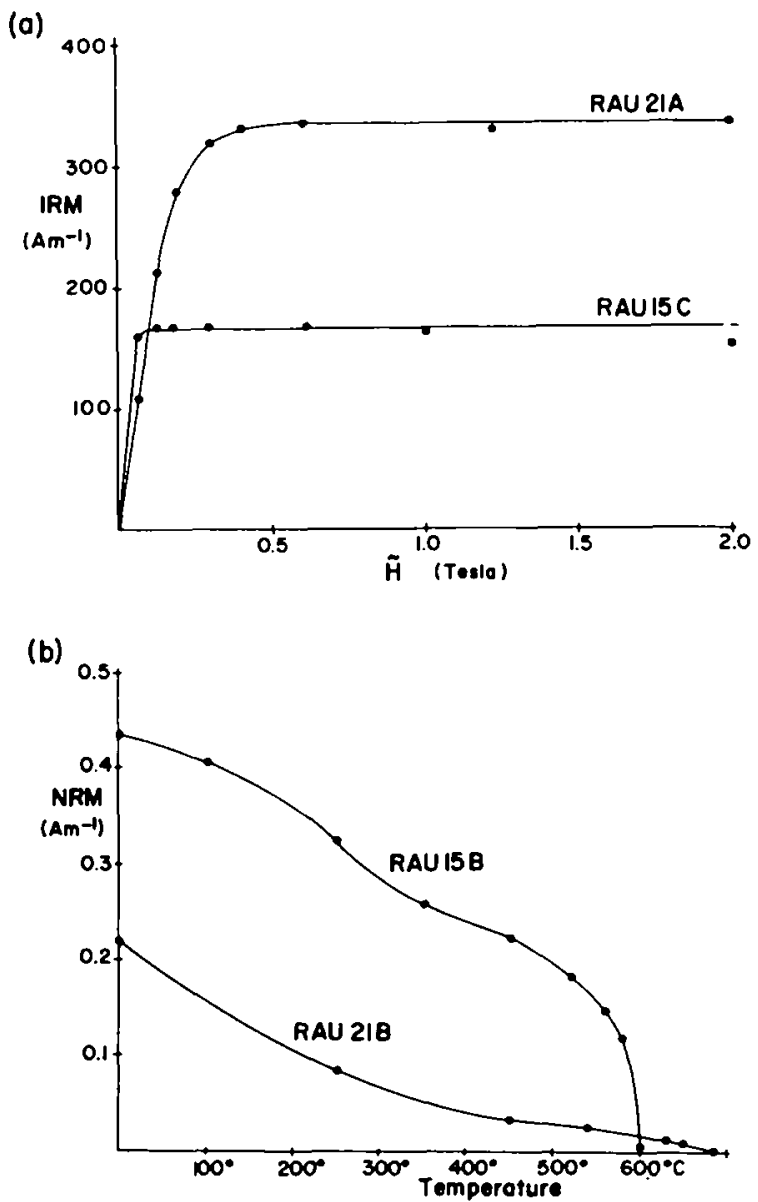

Fig. 4. Diagrams showing the acquisition of isothermal remanent magnetization (IRM) in two samples (top) and NRM intensity vs. temperature during thermal demagnetizations (bottom) for different specimens from the same samples, for site 4 (RAU 15) and site 6 (RAU 21). ing applied fields, becoming saturated at low (less than $0.1 \mathrm{~T}$ ) field strengths, which suggests that magnetite is the predominant magnetic carrier. The NRM in this sample is completely removed by temperatures of $600^{\circ} \mathrm{C}$, also indicating that the magnetic carrier is magnetite. The magnetization of sample RAU 21 included the intermediate as well as the Latest Precambrian/Cambrian direction. It also acquires IRM rapidly with increasing applied fields, but does not become saturated until field strengths of $0.5 \mathrm{~T}$ are reached, suggesting that a mixture of hematite and magnetite is the magnetic carrier. Part of the NRM of this sample persists at temperatures above $600^{\circ} \mathrm{C}$, also indicating that at least part of the magnetization is carried by hematite.

\section{Conclusions and discussion}

The results of the IRM acquisition experiments, the response to thermal demagnetization, the lowgrade regional metamorphism observed in the sampling area, and the intermediate direction, which corresponds to an Ordovician paleopole for North America, lead us to the conclusion that this magnetization was set in the Unicoi basalts by an Ordovician tectono-thermal event, inferred to be related to the Taconic orogeny. Only this component of magnetization (apart from those corresponding to PDF) is found in samples for which the IRM acquisition suggests that magnetite is the predominant carrier. In these samples the magnetization is completely eliminated by temperatures of $600^{\circ} \mathrm{C}$. Thus, we surmise that the initial magnetization acquired when the basalt cooled was completely reset by the tectono-thermal event in these samples. In samples for which the results indicate that hematite is a magnetic carrier in addition to possibly magnetite, the Latest Precambrian/Cambrian direction of magnetization is found. In these samples the magnetizations persist at temperatures above $650^{\circ} \mathrm{C}$. We infer that the presence of hematite in these samples, with its higher blocking temperatures, allowed part of the initial magnetization to survive the later low-grade Ordovician metamorphism. Thus, both the Latest Pre- 


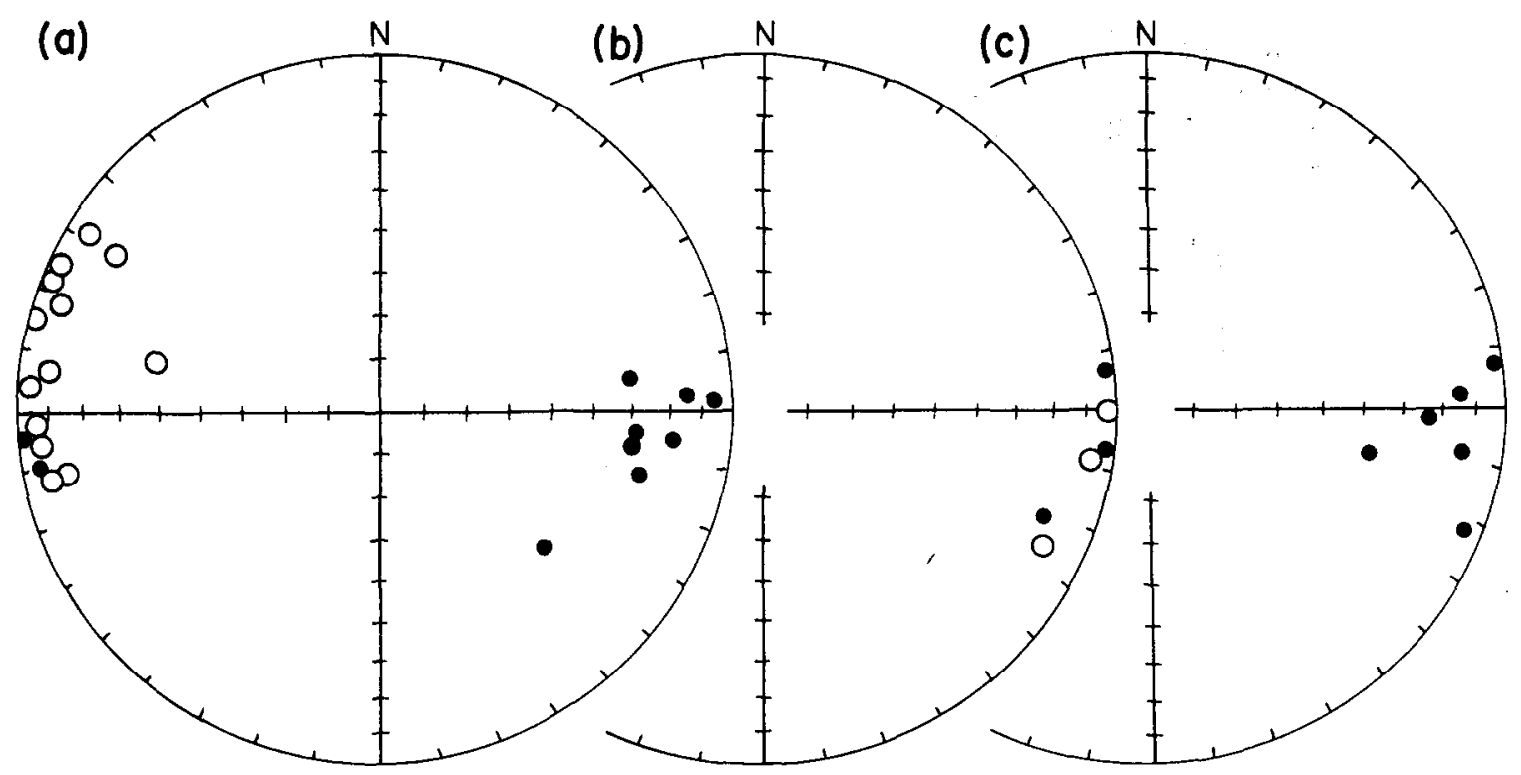

Fig. 5. Equal-area plots of the directions of magnetization for the high-temperature, high-coercivity directions, which are interpreted as Latest Precambrian-Cambrian directions. (a) Sample directions after tectonic correction, (b) site means before, and (c) after tectonic correction (see Table 1). Open (solid) symbols refer to projections on the upper (lower) hemisphere. In (b) and (c), normal-polarity (westerly) directions have been inverted for clarity.

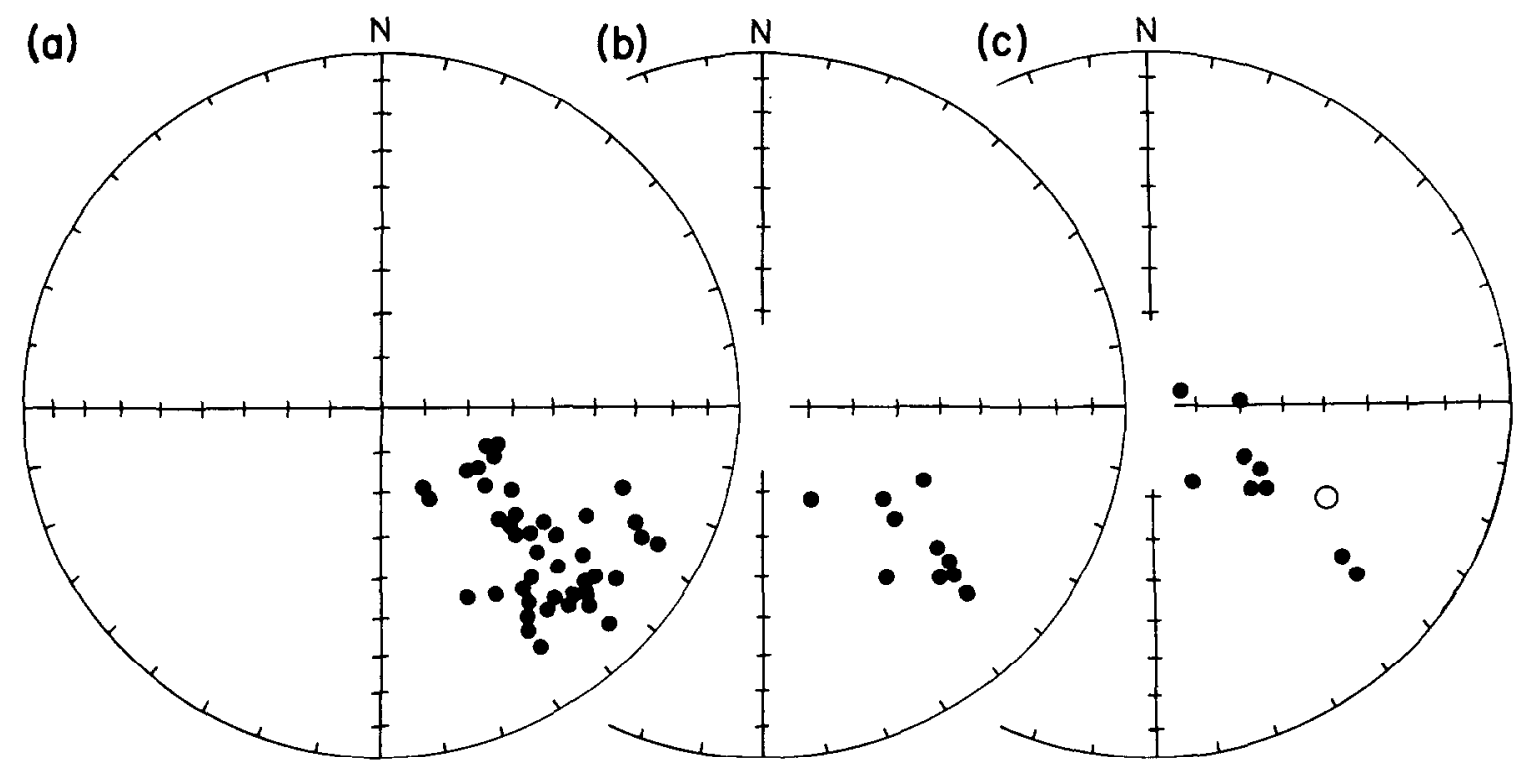

Fig. 6. Equal-area plots (as in Fig. 5) of the intermediate directions of magnetization, which are interpreted as Ordovician directions. (a) Sample directions before tectonic correction, (b) site means before, and (c) after tectonic correction. 
TABLE 2

Paleomagnetic pole positions

\begin{tabular}{lrrrrr}
\hline & $N$ & $D / l$ & $k$ & \multicolumn{1}{c}{$\alpha_{95}$} & Pole position \\
\hline Intermediate directions before tectonic correction & 10 & $131.8 /+42.7$ & 29.4 & 9.1 & $13.7 \mathrm{~N}, 142.5 \mathrm{E}$ \\
Intermediate directions after tectonic correction & 10 & $121.7 /+53.4$ & 5.4 & 22.9 & $1.0 \mathrm{~N}, 143.2 \mathrm{E}$ \\
High-temperature directions before tectonic correction & 6 & $99.3 /-0.1$ & 24.4 & 13.8 & $7.5 \mathrm{~N}, 182.6 \mathrm{E}$ \\
High-temperature directions after tectonic correction & 6 & $95.8 /+16.6$ & 24.4 & 13.8 & $0.4 \mathrm{~S}, 178.0 \mathrm{E}$
\end{tabular}

$D / I$ are the declination and inclination in degrees; $k$ and $\alpha_{95}$ are the statistical parameters associated with the mean directions, giving unit weight to the number $(N)$ of sites.
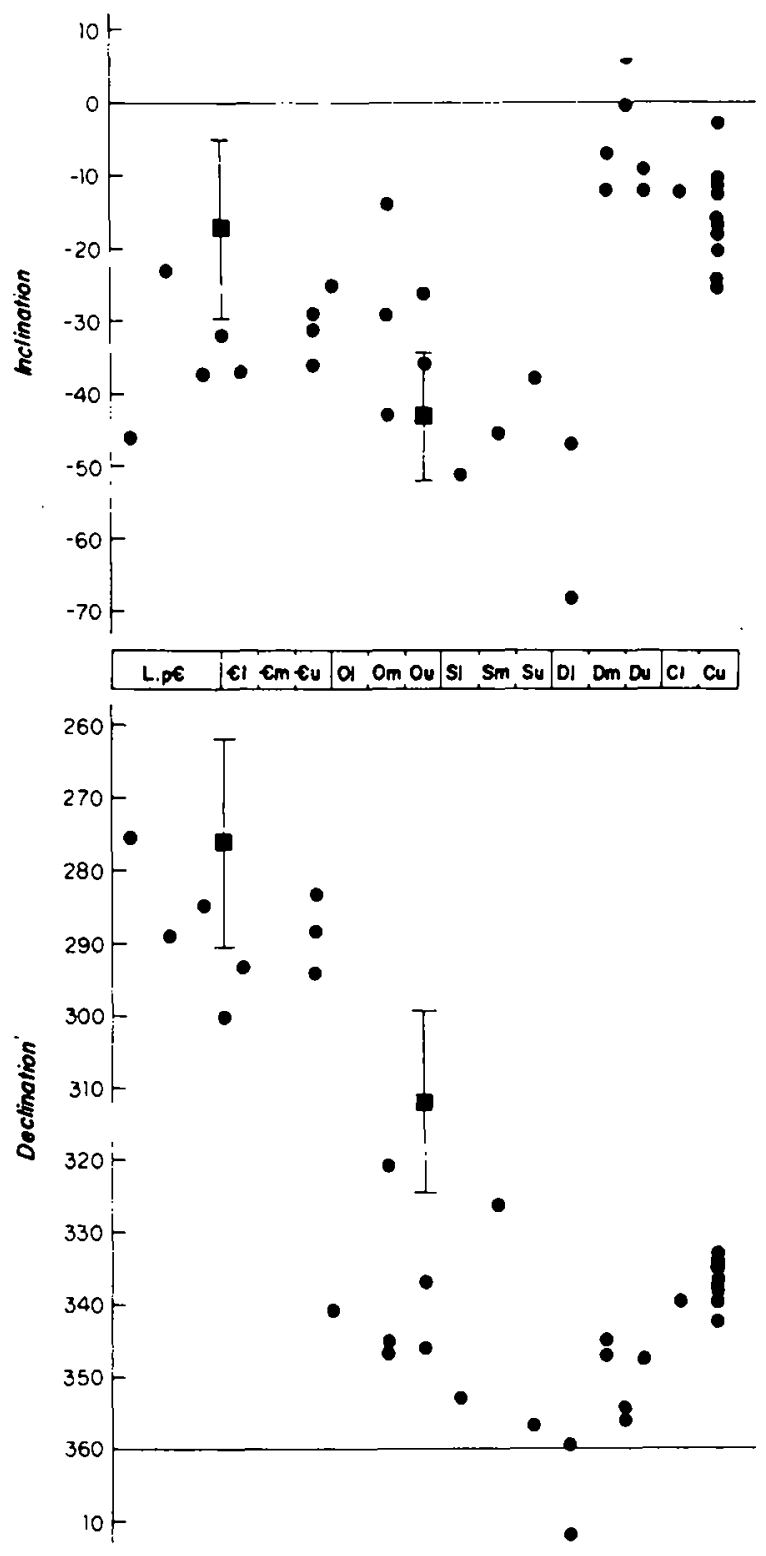

cambrian/Cambrian and the Ordovician direction are found in these samples.

If the original magnetization is carried by hematite, then hematite must be either a primary phase or a very early alteration product. Although hematite was observed in samples from almost all of the sites, only at those sites with hematite as an alteration of ilmenite was the Latest Precambrian/Cambrian direction found. Since ilmenite in basalts must be primary or the result of a hightemperature reaction, it is possible that the hematite was produced at high enough temperatures to record the magnetic field present when the basalt first cooled. The direction of magnetization found suggests that this is indeed the case.

The Latest Precambrian/Cambrian direction was found in samples from six sites. The site means of this direction (Table 1) are plotted in equal-area projection in Fig. 5 . The fold test is inconclusive (Table 2), because of the proximity of the paleomagnetic declinations and the bedding strikes.

The Ordovocian direction of magnetization was found in ten sites. The directions before tectonic

Fig. 7. The directions (squares) obtained from the Unicoi basalts are plotted with directions calculated for our sampling area at the Tennessee-Virginia border from Late Precambrian/Paleozoic poles for cratonic North America. The poles are those listed by Van der Voo [9], plus the latest Precambrian poles from the Frontenac dikes [10], the Franklin diabase [11], the Coronation Sills [12], and the Early Devonian pole from the Canadian Arctic Archipelago [13]. Error bars for inclination correspond to $\alpha_{95}$, and those for declination correspond to $\delta_{95}$, the uncertainty associated with the declination at the $95 \%$ probability level $\left(\delta_{95}=\sin ^{-1}\left(\sin \alpha_{95} / \cos I\right)\right)$ [14]. 
correction and the site means before and after tectonic correction are shown in Fig. 6. The site means cluster better before tectonic correction: the fold test is negative, and statistically so at the $99 \%$ confidence level when applied to site means (Table 2), with a $k_{1} / k_{2}$ ratio [8] of 5.44 . Folding events that may have affected this part of the southern Appalachians are the Taconic, Acadian and Alleghenian orogenies. Therefore, the magnetization must be younger than Cambrian, having been acquired during or after the folding. Since its pole position (Table 2) is close to Ordovician paleopoles for cratonic North America, the folding is presumed to be due to the Taconic orogeny. If true, our results show convincingly that the Blue Ridge in northeast Tennessee and southwest Virginia was affected by the Taconic orogeny, which must have (in the Ordovician) contributed to the present fold-and thrust-structures.

The paleomagnetic directions found in this study are plotted with directions calculated for our sampling area from Latest Precambrian and Paleozoic paleopoles from cratonic North America in Fig. 7. The inclinations and declinations are plotted separately. The inclinations are close to other North American directions of the same age, but the declinations of both the Latest Precambrian/Cambrian and Ordovician directions are about $10-20^{\circ}$ less than expected. This systematic deviation may be explained by a counter-clockwise rotation of the sampled terrane. In view of the allochthony of the terrane [2], this inferred postTaconic counter-clockwise rotation of about 10 $20^{\circ}$ for the Blue Ridge thrust sheet is not at all surprising.

\section{Acknowledgements}

We thank Dr. D.R. Watts, Mr. K.V. Rao and Mr. Chad McCabe for their initial help with the sampling and the measurements, Dr. W.C. Kelly for assistance with reflected light microscopy and . Mr. Erich Petersen for assistance with electron microprobe analysis. All of these colleages as well as Dr. E.J. Essene are thanked for valuable discus- sions. This study was supported by the National Science Foundation, Division of Earth sciences, grants EAR 76-14996 and 81-03031.

\section{References}

1 J.R. Graham, The stability and significance of magnetism in sedimentary rocks, J. Geophys. Res. 54 (1949) 131-167.

2 F.A. Cook, D.S. Albaugh, L.D. Brown, S. Kaufman, J.E. Oliver and R.D. Hatcher, Thin-skinned tectonics in the crystalline southern Appalachians; COCORP seismic reflection profiling of the Blue Ridge and Piedmont, Geology 7 (1979) 563-567.

3 D.R. Watts, R. Van der Voo and R.B. French, Paleomagnetic investigations of the Cambrian Waynesboro and Rome Formations of the Valley and Ridge Province of the Appalachian mountains, J. Geophys. Res. 85 (1980) 5331-5343.

4 D.R. Van Alstine and S.L. Gillett, Paleomagnetism of Upper Precambrian sedimentary rocks from the Desert Range, Nevada, J. Geophys. Res. 84 (1979) 4490-4500.

5 P.B. King and H.W. Ferguson, Geology of northeasternmost Tennessee, U.S. Geol. Surv. Prof. Paper 311 (1960) 136 pp.

6 D.W. Rankin, Guide to the Geology of the Mt. Rodgers area, Virginia, North Carolina and Tennessee in: North Carolina Geological Society Field Trip Guidebook (Chapel Hill, N.C., 1967) $48 \mathrm{pp}$.

7 J.D.A. Zijderveld, A.C. demagnetization of rocks: analysis of results, in: Methods in Paleomagnetism, D.W. Collinson, K.M. Creer, and S.K. Runcorn, eds. (Elsevier, Amsterdam, 1967) 254-286.

8 M.W. McElhinny, Statistical significance of the fold test in paleomagnetism, Geophys. J. R. Astron. Soc. 8 (1964) 338 340.

9 R. Van der Voo, Paleomagnetism of North America: a brief review, in: Paleoreconstruction of the Continents, M.W. McElhinney and D.A. Valencio, eds. (American Geophysical Union, Washington, D.C., 1981) 159-176.

10 G.S. Murthy, The paleomagnetism of diabase dikes from the Grenville Province, Can. J. Earth Sci. 8 (1971) 802-812.

11 W.F. Fahrig, E. Irving and G.D. Jackson, Paleomagnetism of the Franklin diabase, Can. J. Earth Sci. 8 (1971) 455-467.

12 W.A. Robertson and W.R.A. Baragar, The petrology and paleomagnetism of the Coronation sills, Can. J. Earth Sci. 9 (1972) 123-140.

13 P. Dankers, Implications of Lower Devonian poles from the Canadian Arctic Archipelago for the North American apparent polar wander path, Can. J. Sci. (1982) in press.

14 R. Van der Voo, M. Jones, C.S. Grommé, G.D. Eberlein and $M$. Churkin, Paleozoic paleomagnetism and northward drift of the Alexander terrane, southeastern Alaska, J. Geophys. Res. 85 (1980) $5281-5296$. 